\title{
KEBIJAKAN DAN MANAJEMEN STRATEGI REHABILITASI HUTAN RAWA GAMBUT TERDEGRADASI
}

\author{
(Policies and Management Strategies for Rehabilitation of \\ Degraded Peat Swamp Forest)
}

\author{
Oleh/By: \\ Agustinus P. Tampubolon ${ }^{1)}$
}

\begin{abstract}
Rehabilitation of degraded peat swamp forest, especially the failed Mega Rice Project (MRP) in Central Kalimantan, is urgently needed in order to restore its economic and ecological functions. Several policies and management strategies of the rehabilitation have to be decided with considering political, ecosystem, socioeconomic, cultural and institutional aspects which are in line with Minister of Forestry Decree No.20/Kpts-II/2001 and Forest Rehabilitation's ITTO Guidelines. Several policies are addressed covering long run forestry investment, community-based and adaptive forest management approach, alleviation of the poor, forest rehabilitation based on watershed management and forestry decentralization. Three principal management strategies, namely forest restoration of degraded primary forest, management of secondary forest and rehabilitation of degraded forest land and several management strategies of peat swamp forest rehabilitation within the failed MRP are described.
\end{abstract}

Keywords: Peat swamp forest, forest degradation, forest rehabilitation policy, management strategy.

\begin{abstract}
ABSTRAK
Rehabilitasi hutan rawa gambut terdegradasi, khususnya ex-Proyek Lahan Gambut (PLG) Sejuta Hektar di Kalimantan Tengah sangat dibutuhkan untuk memperbaiki fungsi ekonomi dan ekologi hutan yang rusak. Beberapa kebijakan dan manajemen strategi rehabilitasi harus diputuskan dengan memperhatikan aspek politik, ekosistem, sosil ekonomi, budaya dan kelembagaan yang sejalan dengan Keputusan Menhut No. 20/Kpts-II/2001 dan Pedoman ITTO tentang Rehabilitasi Hutan. Beberapa kebijakan dikemukakan meliputi investasi kehutanan jangka panjang, pendekatan pengelolaan hutan berbasis masyarakat dan adaptif, pengentasan penduduk miskin, rehabilitasi hutan berbasis pengelolaan DAS dan desentralisasi kehutanan. Tiga manajemen strategi utama, yakni restorasi hutan primer terdegradasi, pengelolaan hutan sekunder dan rehabilitasi lahan hutan yang terdegradasi beberapa manajemen strategi rehabilitasi hutan rawa gambut ex-PLG diuraikan dalam tulisan ini.
\end{abstract}

Kata kunci:Hutan rawa gambut, degradasi hutan, kebijakan rehabilitasi hutan, manajemen strategi.

'Staf Pusat Litbang Hasil Hutan. 


\section{J umal AnalisisKedijakanKehutanan \\ Vo. 4No 1, Mare 2007: 31 - 38}

\section{INTRODUCTION}

Indonesian forest has been exploited intensively within the last three decades in order to provide wood for forest industries and domestic consumption. Both production forests and conservation forests have been so severely damaged due to excessive forest harvesting and illegal logging followed by uncontrolled forest conversion, forest land encroachment, shifting cultivation and forest fires. The rate of the forest degradation increased sharply from 1995 up to now due to large forest conversion and reformation euphoria. The rate of forest degradation between 1998 - 2003 in Indonesia has been so alarming, which reached about 2.83 million hectares per year. Up to 2002, some 59.7 million hectares of Indonesian forest had been degraded, while further 42.1 million hectares of land are in the states of critical condition. In this regard, lack of control and weak law enforcement contributed to forest degradation (Departemen Kehutanan, 2005).

Indonesian peat swamp forest was also subject to forest degradation. The fact is that deforestation has also been occurring more and more on the fragile peat swamp forest ecosystem (Daryono, 2000; Sjarkowi, 2001). It was mainly caused by excessive logging, as happened in dryland forest, to fulfill expansive forest industry and forest conversion to agricultural use. One of the most degraded peat swamp forest located in Central Kalimantan. The forest ecosystem was extremely destroyed through Mega Rice Project that consisted of 1 million hectares of peatland reclamation.

As peat swamp forest can serve many functions for people prosperity and high quality environment, the Government of Indonesia pays attention to rehabilitate the degraded peat swamp forest. Apart from the rehabilitation activities, the sustainable peat swamp forest is very important to address so that the continual flow of forest products and forest services can be achieved.

The objective of the paper is to provide several policies and management strategies in rehabilitating degraded peat swamp forest especially former Mega Rice Project area in Central Kalimantan.

\section{PROBLEMS ON INDONESIAN PEAT SWAMP FOREST}

The peat swamp forest that occurs in lowland and humid areas has many economic and ecological functions. It can provide several commercial timber species (e.g. ramin, Gonystylus bancanus) and non-timber products, such as damar (from Agathis sp.) and latex (from Dyera lowii), The ecological function of this forest can serve as carbon storage, water retention, water supply, climate stabilization, maintenance biodiversity and flooding control (Rieley, 2001).

International concern is now focused upon the Indonesian peat swamp forest as a major store of carbon which can partly reduce greenhouse gas effect and climate change. Central Kalimantan peat swamp forest, for example, may contain 2,500 tons $\mathrm{C} /$ ha, compared with 1,200 tons $\mathrm{C} / \mathrm{ha}$ in average for peatland globally (Jaya, 2001). The amount of carbon stored in this ecosystem is approximately one third of the total 
carbon stored in global peatland. The accumulation rates of soil organic carbon in Indonesian peat swamp forest varied from 59 to $145 \mathrm{gC} / \mathrm{m}^{2} / \mathrm{yr}$ compared with 8 to $100 \mathrm{~g}$ $\mathrm{C} / \mathrm{m}^{2} / \mathrm{yr}$ in temperate and boreal areas (Jaya, 2001).

There are over 38 million hectares of tropical peatland globally, of which some 20 million hectares (52\%) occur in Indonesia (Radjagukguk, 2001). Most of the peatland in Indonesia is situated at low altitude in the coastal and subcoastal lowlands of Papua, Kalimantan and Sumatera, and small amount is located in Java, Halmahera and Sulawesi (Sumawinata, 2000).

Tropical lowland peat soil is a marginal land. The soil is characterized by a very low $\mathrm{pH}$ (3-4), low chemical fertility, very low bulk density, a high porosity, a very high water holding capacity, and tendency to subside upon drainage and cultivation (Radjagukguk, 2001). After drainage and land clearing, a rapid subsidence of the peat layers occurs. In the early stage of reclamation, subsidence may occur at the rate 50-60 cm per year, subsequently slowing down to $2-5 \mathrm{~cm}$ per year. If the soil is drained and cultivated intensively, the oxidation will occur and some toxic elements will be exposed to the soil surface and therefore harmful to the plants. In the dry season, the soil is then susceptible to the fire. Fire will destroy the soil and burn out its vegetation. The soil shrinks and never revert to the initial condition (irreversible) (Radjagukguk, 2001).

The degradation of peat swamp forest in Indonesia took place since the 1970s as a result of uncontrolled and illegal logging, forest conversion for agricultural land and crop estates, transmigration settlements and wildfires (Daryono, 2000). For example, the execution of Mega Rice Project (MRP) in Central Kalimantan and forest conversion into agricultural land associated with transmigration settlement in Riau and Jambi caused detrimental effect on peat swamp forest ecosystem. Regarding wildfires, the El Nino phenomenon in 1997 has burnt out 1.45 million hectares of the forest (Page et al. 2000 in Mubammad and Rieley, 2001).

It can be said that the worst peat swamp forest degradation in Indonesia occurred when the MRP was executed for rice's self- sufficiency reason (Mulyanto, 2000). The MRP was initiated in 1995 by the Presidential Decree No.82 with aim of converting one million hectares of the forest into rice fields (Tim Ad Hoc Penanganan Eks Proyek PLG, 2005). The project is located in 3 Districts, namely Barito Selatan, Kuala Kapuas and Palangkaraya. Approximately, 4,000 km of drainage and irrigation channels were developed in the respective area into 2 years and then hundreds of transmigrants were sent to the area. Unfortunately, the project was failed and ceased in 1999 as a result of technical failure, lack of understanding of appropriate land use and socio-economic and cultural aspects of both local people and settlers and peak economic crisis (Mulyanto, 2000).

\section{POLICIES OF THE REHABILITATION}

In order to formulate policies on rehabilitation of degraded peat swamp forest, we should consider policy priorities of Ministry of Forestry. In other words, the 


\section{J umal AnalisisKedijakanKehutanan \\ Vo. 4No 1, Mare 2007: 31 - 38}

rehabilitation policies should be in line with the forestry policy priorities. Minister of Forestry has already declared Decree No.SK.456/Menhut-VII/2004 concerning five policy priorities of forestry sector, as follows:

1. Elimination illegal logging in state forest and illegal trading;

2. Revitalization of forestry sector, especially forest industry;

3. Rehabilitation and conservation of forest resources;

4. Empowerment of community economy who live in the forest and around the forest;

5. Promoting sustainable forest management through the establishment of Forest Management Unit.

The five policy priorities are aimed to achieve good forestry governance and social forestry with considering the actual condition of forest resources and the application of sustainable development principles. In this regard, rehabilitation and conservation have important role in order to achieve forest perpetuity and people prosperity. Even though these activities are costly, the successful rehabilitation schemes will improve the human's life and environment quality. Before conducting the activities, policy formulation should be properly conducted and forest degradation should be clearly defined (ITTO, 2002).

Degraded peat swamp forest was less accommodated in forest policy in the past compared to the dryland forest. There was a lack of policies regulating and encouraging its rehabilitation and management. Obviously, there has been more evident indicating that the peat swamp forest ecosystem provides a lot of intangible and tangible benefits. The lack of a policy focusing on the forest is caused by several factors, namely lack of information on the extent and values of the forest resources, inadequate knowledge on ecology, silviculture and rehabilitation technology, low political priority and constraint of financial resources. These factors can be said as constraints to conduct rehabilitation activities.

Due to huge peat swamp forest degradation caused by failed Mega Rice Project in Central Kalimantan, wildfire and unsuccessful forest conversion for transmigration settlements in Riau and Jambi, Ministry of Forestry has considered the importance of rehabilitating the degraded peat swamp forest. Budgets were allocated to the districts that have degraded forest area in the scheme of National Movement on Forest and Land Rehabilitation.

Besides the budget, Ministry of Forestry also facilitated the rehabilitation activities through provision of regulations. One of the regulations is Minister of Forestry Decree No. 20/Kpts-II/2001 concerning General Pattern, Standard and Criteria of Forest and Land Rehabilitation (Departemen Kehutanan, 2000). This decree considered political, ecosystem, social, cultural and institutional aspects. The implementation of the rehabilitation, in this context, should follow precondition phase and action phase. The forest and land rehabilitation system consists of object, technology and institution components that were arranged in matrix of criteria and indicators. In that matrix, three components are set up in management functions (planning, organizing, implementing and controlling) and elements of the components (planning unit, tenure, function (for forest area); human resources, organization, authority, work relationship (for institution); and technology, public role and incentive/disincentive. 
In order to rehabilitate degraded peat swamp forest, several policies can be addressed, as follows:

1. rehabilitation is valued as a long time forestry investment that can guarantee continual flow of forest goods and services;

2. rehabilitation is conducted through community-based forest management and adaptive management approach that can attain commitment, community involvement and participation;

3. rehabilitation should make valuable contributions to rural livelihoods, particularly those of the poor;

4. policy intervention on forest rehabilitation is needed to some extent in order to increase the attractiveness of the rehabilitation and profitability of forest rehabilitation;

5. rehabilitation should be conducted in watershed management unit basis;

6. rehabilitation should be in line with forest decentralization with applying effective forest governance (ITTO, 2002).

\section{MANAGEMENT STRATEGIES OF THE REHABILITATION}

Management strategies in forest rehabilitation aim to enhance the functionality of degraded forest. They should be based on a sound analysis of the general social, economic, institutional and ecological context. The rehabilitation is conducted on landscape scale based on specific local conditions. In general terms, management strategies for degraded forest aim to regain ecosystem integrity and to enhance human well-being.

Based on the level of forest degradation, there are three principal management strategies, namely forest restoration; management of secondary forests; and rehabilitation of degraded forest land (ITTO, 2002). The three management strategies should be implemented in Indonesia with considering the magnitude of forest degradation, socioeconomic and institutional aspects. Forest restoration is the principal management strategy applied to degraded primary forest. Secondary forests are managed for multiple purpose, such as producing timber, firewood, non timber forest products and water. Options may include management for wood and non-wood forest products and the provision of environmental services. The rehabilitation of degraded forest land is required at sites where mismanagement has led to total replacement of forest.

In formulating the management strategies of rehabilitation of degraded peat swamp forest, we should consider several socio-cultural aspects, as follows, existing land use system; value system of local people and migrants; community organization; cost/benefits sharing; right to use and to process; empowerment of local people institution; the status of traditional knowledge; social equity and gender awareness (ITTO, 2002).

Economic and institutional aspects have very strong influence on deciding the management strategies of degraded peat swamp forest. It consists of the causes of forest degradation; local and national interests; incentive systems; existing organization; monitoring process; and production/marketing of timber and non timber products. 


\section{J umal AnalisisKedijakanKehutanan \\ Vo. 4No 1, Mare 2007: 31 - 38}

The ecological aspects should be considered in formulating management strategies. They consist of landscape approach; site-specific condition; productive and protective functions; water, soil and climate factors; biodiversity; status of traditional/appropriate technology; and resource optimization.

The following we propose some management strategies for rehabilitation of peat swamp forest areas within the MRP in Central Kalimantan:

1. Management objectives of forest restoration, secondary forest management and rehabilitation of degraded peat swamp forest should be clearly decided. In this context, the objectives can be conservation, timber production, multiple forest use or site improvement.

2. Degraded primary peat swamp forest can be managed for wood production or multiple-use whereas secondary peat swamp forest can be managed as part of an agroforestry system or as a high-forest production system;

3. Degraded peat swamp forest land can be managed with introducing lightly managed plantings in order to catalyze natural forest succession or planting trees under agroforestry;

4. Clear forest and land resource use rights must be provided to the local people as far as those rights can support sustainable forest management and rehabilitation activities;

5. Local communities and stakeholders are asked to participate and share the responsibility for decision-making in planning and implementing restoration, management and rehabilitation strategies;

6. The local people are allowed to capture the benefits from rehabilitation activities;

7. Market and non-market costs and benefits are needed to be shared by all stakeholders;

8. Indigenous knowledge should be used in the rehabilitation activities;

9. The management of degraded and secondary forests should be based on sound ecological and silvicultural knowledge;

10. Soil characteristics are needed to be maintained and improved to guarantee efficient stand restoration and rehabilitation;

11. Economic and financial viability is essential for the restoration, rehabilitation and management of degraded forest;

12. Applied research is essential to guide adaptive management and silviculture techniques.

Besides the above recommendations, we should adopt Sjarkowi's (2001) suggestions in avoiding social entropy (negative social changes) in forest rehabilitation process and facilitating adequate instruments, such as SDP (Spatial Development Plan), RDP (Regional Development Plan), CDP (Community Development Plan), IDP (Institutional Development Plan) and BDP (Business Development Plan) for the implementation of rehabilitation activities. 


\section{CONCLUSIONS AND RECOMMENDATIONS}

\section{A. Conclusions}

1. The formulation of policies in rehabilitating degraded peat swamp forest, especially the failed Mega Rice Project in Central Kalimantan, can be done with exploring substances of Minister of Forestry Decree No.20/Kpts-II/2001 concerning General Pattern, Standard and Criteria of Forest and Land Rehabilitation and Forest Rehabilitation's ITTO Guidelines.

2. The policies cover: (i). forest rehabilitation is valued as a long time forestry investment; (ii). forest rehabilitation adopts community-based forest management and adaptive management approach; (iii). forest rehabilitation has benefits for rural livelihoods; (iv). government intervention is needed to increase the attractiveness and profitability of forest rehabilitation; (v). forest rehabilitation is based on watershed management; (vi). forest rehabilitation fits with forest decentralization.

3. Based on the level of forest degradation, there are three principal management strategies, namely forest restoration of degraded primary forest, management of secondary forest and rehabilitation of degraded forest land.

4. Twelve management strategies of peat swamp forest rehabilitation are needed covering clear management objectives, recommended silviculture techniques based on sound ecological knowledge and applied research outputs, promoting indigenous knowledge, local people participation and rights, capturing benefits for local people and creating economic and financial viability of the rehabilitation.

\section{B. Recommendations}

1. Dominant government role in rehabilitating failed Mega Rice Project in Central Kalimantan through National Movement on Forest and Land Rehabilitation scheme should be transformed into local people initiatives with improving capacity building and adaptive management system.

2. Government should provide adequate incentives and technical assistance to the local people so that rehabilitation activities become attractive and profitable.

\section{REFERENCES}

Daryono, H. 2000. Kondisi Hutan Setelah Penebangan dan Pemilihan Jenis Pohon yang Sesuai untuk Rehabilitasi dan Pengembangan Hutan Tanaman di Lahan Rawa Gambut. dalam Daryono, H. et al.(eds.). Prosiding Seminar Pengelolaan Hutan Rawa Gambut. Bogor. p.2143.

Departemen Kehutanan. 2000. Pola Umum dan Standar Serta Kriteria Rehabilitasi Hutan dan Lahan. Jakarta. 


\section{J umal AnalisisKedijakan Ketutanan}

Vo. 4No 1, Mare 2007: 31 - 38

Departemen Kehutanan. 2005. Rencana Strategis Kementerian Negara/ Lembaga Departemen Kehutanan Tahun 2005- 2009. Jakarta.

ITTO. 2002. ITTO Guidelines for the Restoration, Management and Rehabilitation of Degraded and Secondary Tropical Forests. ITTO Policy Development Series. No.13. Yokohama. Japan.

Jaya, A. 2001. Carbon Storage in Tropical Peatlands. Tropical Peatlands. 1(1): 1115.

Muhammad, N.Z., and J. Rieley. 2001. Management of Tropical Peatlands: Mega Reclamation Project in Central Kalimantan. Tropical Peatlands. 1(1): 30-32.

Mulyanto, B. 2000. Pendekatan dan Strategi Pemanfaatan Hutan Rawa Gambut Eks PLG Sejuta Hektar. dalam Daryono, H. et al.(eds.). Prosiding Seminar Pengelolaan Hutan Rawa Gambut. Bogor. p.18.

Radjagukguk, B. 2001. Sustainable Agriculture on Tropical Peatlands. Tropical Peatlands. $1(1): 24-26$.

Rieley, J. 2001. Overview of Tropical Peatlands: Location, Extent, Importance and Impact. Tropical Peatlands. 1(1): 17.

Sjarkowi, F. 2001. Socio-entropy System Approach ('Sesa') Towards Sustainable Management of Peatland Forest Ecosystem in Central Kalimantan. Tropical Peatlands. 1(1): 48-63.

Sumawinata, B. 2000. Pemikiran Ulang Prinsip Penataan Daerah Konservasi Hutan Rawa Gambut. dalam Daryono, H. et al.(eds.). Prosiding Seminar Pengelolaan Hutan Rawa Gambut. Bogor. p.15-20.

Tim Ad Hoc Penanganan Eks Proyek PLG. 2005. Perencanaan Pengembangan dan Pengelolaan Kawasan Eks Proyek PLG. Jakarta. 